729 傾斜内壁をもつ矩形断面往復流路内流動の PIV 計測

\title{
PIV Measurement in two-pass rectangular channels with an inclined divider wall
}

\author{
正 中山 浩 (名大)，○正 廣田 真史 (名大)，正 藤田 秀臣（名大） \\ 蔡否 (名大院), 倉本 博幸 (エプソン)
}

Hiroshi NAKAYAMA, Masafumi HIROTA, Hideomi FUJITA and Lei CAI,

Nagoya University, Furo-cho, Chikusa-ku, Nagoya University

Hiroyuki KURAMOTO, Seiko EPSON Co., Matsumoto, Nagano

Keywords: Forced convection, Velocity measurement, Heat exchanger, LDV

\section{1. 藉論}

シャープターンをもつ矩形断面往復流路では, 遠心力に起 因する 2 次流れと大規模な流れのはく離, 再付着が共存する ため, 流路内の流動は極めて複雑となり, 流路内の熱伝達特 性は複雑に変化することが知られている(1).

これまで, 著者らは高空間分解能が得られるナフタレン昇 華法を用いて，シャープターンをもつ矩形流路内の全壁面に わたる局所伝熱特性を実験的に明らかにしてきた(2)．特に流 路内壁（隔壁）を外壁に対して傾斜させた場合には，局所熱 伝達特性に大きな影響が及び,また傾斜角度の最適化により， 平均熱伝達率の増大, 流動抵抗の低減, 熱伝達率分布の一様 性向上,など熱交換器により適した伝熱特性が得られる可能 性を指摘してきた (3). しかし，その伝熱特性に多大な影響を 及ほす内部流動については, 流動特性が複雑なこともあって 十分な研究は行われていない.このような流路の流動特性を 明らかにすることは，工学的に興味深いだけでなく，より高 効率な伝熱機器の設計にも有用な知見を与えることになる.

本研究では, 傾斜内壁を有する長方形断面のシャープター ン流路（図2）において，3種類の傾斜角度に対して, 非接触 で多点同時計測が可能なPIV 法を用いて流路内の速度分布を 計測し, 隔壁傾斜角度が隔壁先端部におけるはく離泡の形成, ターン後の二次流れのパターンなどに及ほす影響について検 討した。

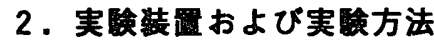

図1にPIVによる実験装置の概要を示す．作動流体には室 温空気を用い, 流路系は吸い込み式とする. 室温空気は整流 室を経てシャープターンを持つ測定流路に流入し，フィル ターおよび流量計を通過後, 送風機により実験室外に排出さ れる. 測定流路入口はバッフル板を取り付けて, 流入空気を 強制的にはく離，急縮小させた ${ }^{(3)}$.

図 2 に測定領域の詳細と各壁面の名称を示す．流路は入口 断面 $40 \mathrm{~mm} \times 20 \mathrm{~mm}$ (水力直径 $d_{h}=26.6 \mathrm{~mm}$ ) をもつ矩形流路であ $\eta$, 流路長さ $226 \mathrm{~mm}$, 流路隔壁を厚さ $T_{d}=8 \mathrm{~mm}$, 夕ーン部の 間隙寸法 $C$ を $40 \mathrm{~mm}$ として, 流路隔壁の傾斜角度 $\alpha$ を $+4^{\circ}$ (拡 大流路)， $0^{\circ}$ (平行流路)，-4(縮小流路）の 3 通りに変化さ せた．流路入口で定義したレイノルズ数 $R e=U_{b} d_{h} / v=3.5 \times 10^{4}$

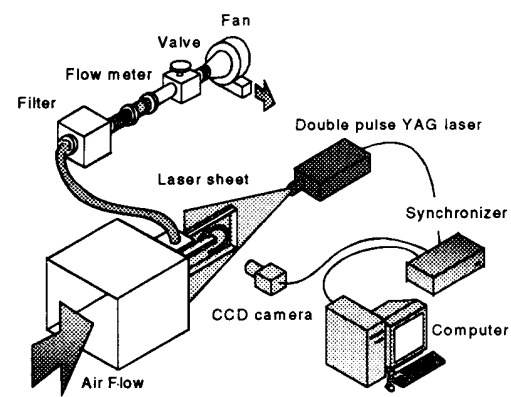

Fig.1 Experimental apparatus
$\left(U_{b}:\right.$ バルク速度, $v$ : 動粘性係数) の条件下で実験を行った. 座標系の原点は $\alpha=0^{\circ}$ の場合の隔壁先端中央とし, 上流側の 主流方向を $X$ 軸, 長辺壁スパン方向, 短辺壁スパン方向をそ れぞれ $Y$ 軸, $Z$ 軸と定めた. 流路の無次元化にはそれぞれ水力 直径, 流路幅 $(2 A)$, 流路高さ $(2 B)$ を用いて, $X^{*}=X I d_{h}, Y^{*}=Y I$ $(2 A+T / 2), Z^{*}=Z / B$ と定義した. $X, Y, Z$ 方向の平均速度成分 はそれぞれ $U, V, W$ と表す。

速度計測に用いたPIVシステムは, 撮影用光源としてダブ ルパルス YAGレーザシート光（出力：15mJ, 波長：532nm, 発光半値幅: $5 \mathrm{~ns}$, シート光厚さ: $0.5 \mathrm{~mm}$ ), 相関カメラ (640×480pixel, 8bit) とレーザとカメラを同期させるシンクロ ナイザおよびコンピュータから構成されている. 本計測では トレーサとしてプロピレングリコールの煙を使用し, 発光時 間間隔 $\Delta t$ を 10〜 30 $\mu$ Sに設定して測定断面を可視化した. PIV の解析には濃度相関法を適用し, 速度べクトルの算出にはサ ブピクセル補間を用いた。また設定した検査空のサイズは $31 \times 31$ pixel, 探査領域は 40×40pixel とした. 今回は 1000 枚の瞬 時画像 (500ペア) を用い, 時間平均速度分布を算出し, 流れ 場の時間平均的挙動を調べた.

\section{3. 実験結果および考案}

\section{1 流路対称断面内の流れ}

図3(a)，3(b)，3(c)にそれぞれ $\alpha=0^{\circ},-4^{\circ},+4^{\circ}$ の場合の流路 対称面上 $\left(Z^{*}=0\right)$ における速度ベクトル分布およびバルク速 度で無次元化された平均速度分布 $\left(U^{2}+V^{2}\right)^{1 / 2} / U_{b}$ を示す。

まずターン前の部分に注目すると， $\alpha=0^{\circ}$ では， $Y$ 方向に対 して対称な速度分布を示しており， $X^{*}=-1$ からターン部の影 響が現れ始め, 高速流体が隔壁側に偏り, ターン内へ流入し ていく様子が見られる， $\alpha=-4^{\circ}, \alpha=+4^{\circ}$ では, 流路の縮小・拡 大に伴い，それぞれ主流が下流方向に加速，減速している様 子が見られる。

ターン部に流入した流れは, 端面に衝突して減速すると同 時にYの正方向へ向きが変えられ，その後，ターン下流外壁 に再衝突する， $\alpha=-4^{\circ}$ ではターン部に流入する流体の流速が 大きいため, 端面に衝突する流れは強く, $Y^{*}=-0.5 \sim 0.5$ の領域 で端面 (End wall) 側に高速流体が偏る傾向が見られる.一方, $\alpha=+4^{\circ}$ では端面に衝突する流れは $\alpha=-4^{\circ}$ に比べて弱く，隔壁

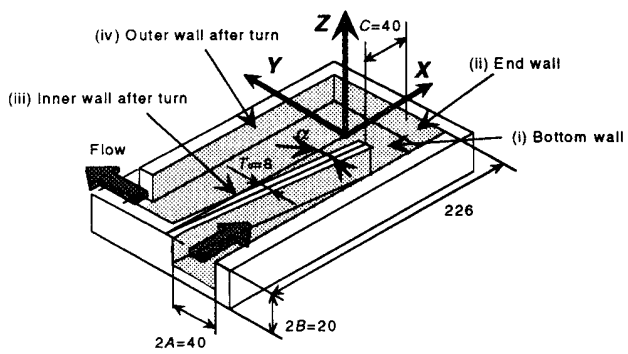

Fig. 2 Details of the test section ( $\alpha=-4^{\circ}$, convergent channel)

山梨講演会講演論文集（共催 日本機械学会関東支部・精密工学会, 2001-10-20, 甲府） 
側の先端部で流れが加速される傾向が見られる.いずれの流 路でも端面に衝突した流れの一部分はターン前半コーナー部 で逆流し, 循環領域を形成する。この循環領域は $\alpha=+4^{\circ}, 0^{\circ}$, $-4^{\circ}$ の順に小さくなる.なお，ターン後半コーナー部には，い ずれの場合にも明確な循環領域は観察されない.

ターン下流の領域では，流れ場に及はす $\alpha$ の影響が顕著に 認められる． $\alpha=0^{\circ}$ の場合では隔壁先端からはく離して $X^{*}=$ -2.6 付近の隔壁上に再付着する流れが見られ，隔壁に沿って はく離泡が形成される.この結果外壁側の流速は最大で $U_{b}$ の 2.2 倍になる。 $\alpha=-4^{\circ}$ の場合にははく離泡が大きく発達し，外 壁側に最大速度が $U_{b}$ の 2.2 倍程度の高速度領域をもつスパン

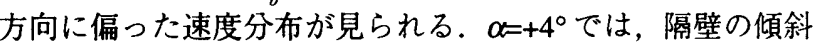
と流れのはく離による実質的な流路断面積が小さくなるため, この領域を通過する流体の速度は外壁側でU。2.6倍に達し， またはく離泡のスケールは他の流路に比べ小さくなる．

\section{2 晰面 2 次流れ}

図 4(a)，4(b)，(c)にそれぞれ $\alpha=0^{\circ},-4^{\circ},+4^{\circ}$ の場合の断面 2 次流れを示す。これらの図において左側は隔壁側, 右側は 外壁側（ターン内では端面）を示している。 また，それぞれ の流路における3 種類の図は, 流路の3 断面 (ターン中間部, ターン出口部, ターン下流部）を示している.

ターン中間部では, いずれの流路でもターン部に流入した
流体が外壁（端面）に衝突した後，一部の流体が上下面に吹 き降ろし，この壁面に沿って隔壁側に戻るといった 1 対の渦

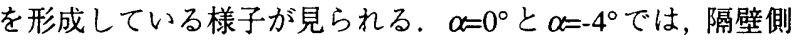
にははく離泡に対応する低速度領域が見られるが， $\alpha=+4^{\circ} て ゙$ は, 隔壁側の低速度領域はごく小さく, 隔壁から端面まで広 がる大規模な渦構造を示す.

ターン出口部では, ターン中間部と同様に, いずれの流路 でも外壁側に1対の渦を形成し, その渦は $\alpha=-4^{\circ}, 0^{\circ},+4^{\circ}$ の 順に強くなることがわかる， $\alpha=-4^{\circ} て ゙ は ，$ 最大で $U_{b}$ の約 0.75 倍の流れが生じているが, 他の流路に比べて2次流れは弱く, 全体的に外壁側に向かう流れが生じている。一方， $\alpha=+4^{\circ} の$ 流路においては, 流路縮小の効果により2次流れの大きさは 最大で $U_{b}$ の3.26倍に達し, 外壁に向かう強い流れが形成され る。

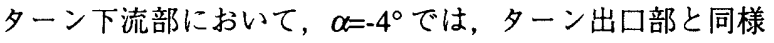
に，外壁側にわずかに渦構造が見られるが，全体的にこ次流 れはさらに弱まる傾向を示す， $\alpha=+4^{\circ}$ では，外壁側の渦のス ケールがターン出口よりも大きくなり, 上下壁に沿って隔壁 に向かう流れが支配的になることがわかる。

\section{参考献}

(1) Metzger et al., J Heat Transfer, 108 (1986), 500.

(2) 廣田 ·他 5 名, 機論, 64-625, B(1998), 2977.

(3) 廣田 ·他 4 名, 機論, 67-656, B(2001), 1012.

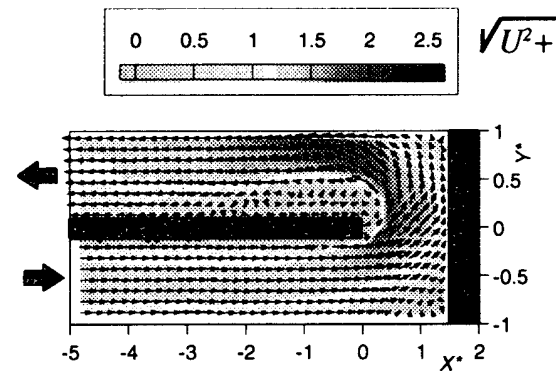

(a) Standard channel $\left(\alpha=0^{\circ}\right)$

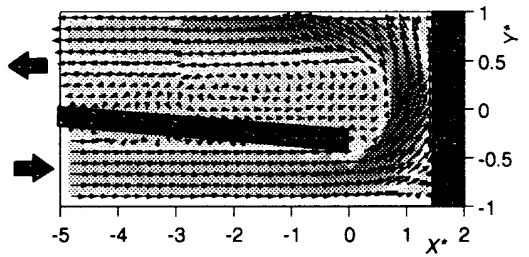

(b) Convergent channel $\left(\alpha=-4^{\circ}\right)$

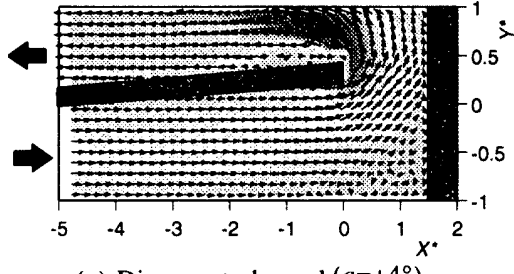

(c) Divergent channel $\left(a=+4^{\circ}\right)$

Fig.3 Mean velocity vector maps and distribution maps
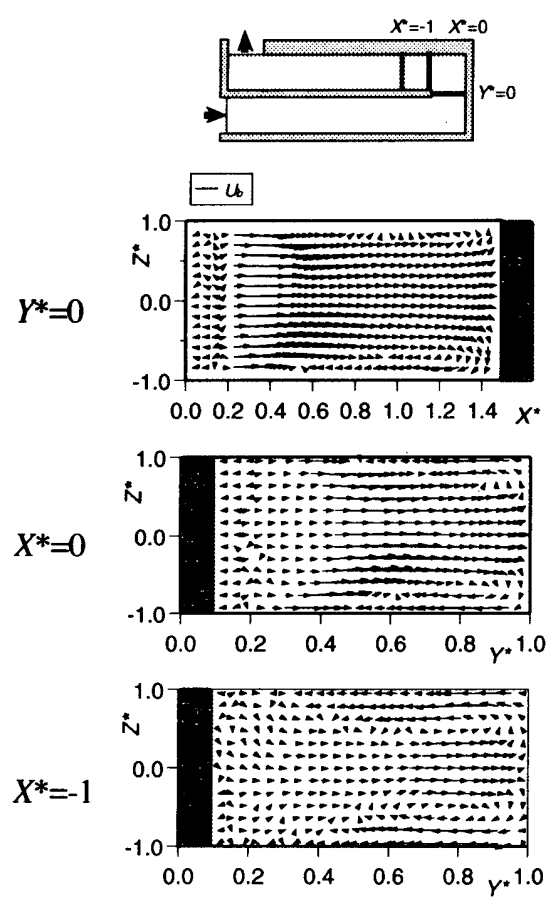

(a) Standard channel $\left(\alpha=0^{\circ}\right)$
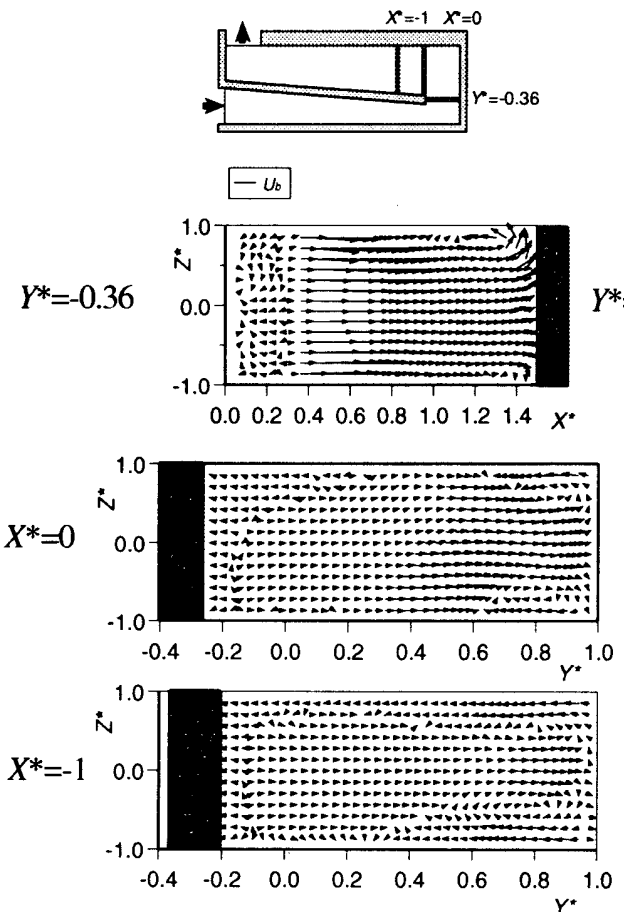

(b) Convergent channel $\left(\alpha=-4^{\circ}\right)$

Fig.4 Secondary flow vector maps
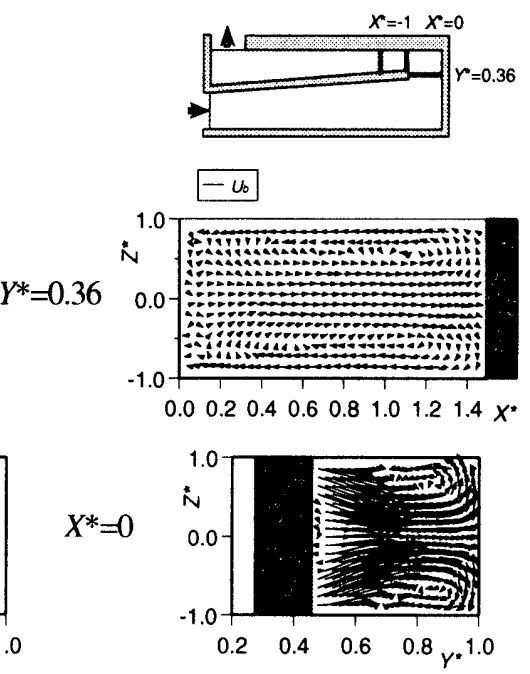

$X^{*}=-1$

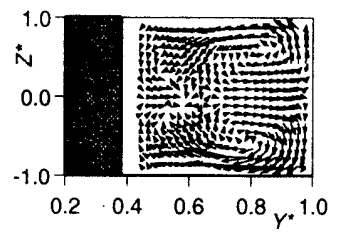

(c) Divergent channel $\left(\alpha=+4^{\circ}\right)$ 